\title{
DEREGULATION, LIBERALIZATION AND CONSOLIDATION OF THE MEXICAN BANKING SYSTEM: EFFECTS ON COMPETITION*
}

\author{
Joaquín Maudos and Liliana Solís**
}

WP-EC 2007-13

Corresponding author: J. Maudos, Instituto Valenciano de Investigaciones Económicas (Ivie), c/ Guardia civil, 22, Esc. 2a , 1º, 46020 Valencia (SPAIN). Tel: 349631900 50, Fax: 349631900 55; E-mail: joaquin.maudos@ivie.es.

Editor: Instituto Valenciano de Investigaciones Económicas, S.A.

Primera Edición Diciembre 2007

Depósito Legal: V-5104-2007

IVIE working papers offer in advance the results of economic research under way in order to encourage a discussion process before sending them to scientific journals for their final publication.

\footnotetext{
* The authors acknowledge the financial support of the Valencian Institute of Economic Research (Ivie) and the comments of an anonymous referee. Liliana Solís also thanks the Banco de Mexico for the information provided and the National Council for Science and Technology (CONACYT) and Carolina Foundation for their financial support. The study has been carried out within the framework of the research programs of the Spanish Ministry of Education and Science -FEDER (SEJ2005-02776 and SEJ2004-00110).

${ }^{* *}$ L. Solis and J. Maudos: Universitat de València, Departamento de Análisis Económico.
} 


\title{
DEREGULATION, LIBERALIZATION AND \\ CONSOLIDATION OF THE MEXICAN BANKING SYSTEM: EFFECTS ON COMPETITION
}

\author{
Joaquín Maudos and Liliana Solís
}

\begin{abstract}
This paper analyses the evolution of competition in the Mexican banking system in the period 1993-2005, a period of deregulation, liberalization and consolidation of the sector. For this purpose we use two indicators of competition from the theory of industrial organization (the Lerner index and the Panzar and Rosse's $H$-statistic). The empirical evidence does not permit us to reject the existence of monopolistic competition. The Lerner index shows a decrease in competitive rivalry in the deposit market and an increase in the loan market, a cross subsidization strategy being observed. The results obtained call into question the effectiveness of the measures implemented hitherto, aimed at increasing the competitiveness of the Mexican banking system.
\end{abstract}

Key words: banking, competition, deregulation

JEL: G21, L10

\section{RESUMEN}

Este artículo analiza la evolución de la competencia en el sistema bancario Mexicano en el periodo 1993-2005, periodo de desregulación, liberalización y consolidación del sector. Para ello se utilizan dos medidas de competencia derivadas de la teoría de la Organización Industrial: el índice de Lerner y el estadístico $H$ de Panzar y Rosse. La evidencia empírica no permite rechazar la existencia de competencia monopolística. El índice de Lerner muestra una disminución en la rivalidad competitiva en el mercado de los depósitos y un incremento en el mercado de los préstamos, observándose una estrategia de subsidiación cruzada entre ambos mercados. Los resultados obtenidos cuestionan la efectividad de las medidas hasta ahora implementadas dirigidas a incrementar la competencia en la banca Mexicana.

Palabras clave: banca, competencia, desregulación. 


\section{Introduction}

In recent years the Mexican banking system has undergone major changes, such as its nationalization in 1982, privatization in 1991, the financial crisis of December 1994 and its gradual opening-up to foreign investment, beginning in 1994. It was not until December 1998 that the restrictions on banking activity were completely lifted.

In this context, several studies have analyzed the effect on the Mexican banking system of the events occurring during this period. Thus, in the case of privatization, Unal and Navarro (1999) show that the Mexican government was very careful to ensure due process and transparency through the entire bank privatization process. However, the lack of a legal and regulatory framework and lax oversight shadowed the success of the technical process. For his part, Haber (2005) analyses the privatization of the banking system and argues that the government's objective was to privatize an oligopolistic banking industry and maximize its revenue.

In relation to the opening-up of the Mexican banking market to foreign capital, though there are no studies referring exclusively to the case of Mexico, the literature on emerging countries does not show any conclusive results. On the one hand, authors such as Levine (1996), Demirgüç-Kunt et al. (1998) and Claessens et al. (2000) offer arguments and evidence favourable to opening-up, while other authors (such as Kaminsky and Reinhart, 1999) show arguments against.

The events described above can affect the degree of competition in the Mexican banking markets, and consequently the country's economic development. In this respect, the analysis of competition in the banking sector is important, since the exercise of market power brings with it a social inefficiency that translates into a loss of social welfare (the so-called Harberger triangle), an increase in financial intermediation costs, and consequently slower growth of investment and production.

Conscious of the importance of the analysis of banking competition, other studies have focused on the analysis of the effect of the events described on the evolution of competition in the specific case of the Mexican banking system. Thus, Gruben and McComb (2003) estimate an index of market power with aggregate data and identify a change in competitive behaviour due to privatization. The results obtained by the authors suggest bank behaviour that is consistent with competitiveness before the privatization but with super-competitiveness after privatization in which banks run at levels of output where marginal costs exceed marginal revenues. Dueñas 
(2003) measures competition and banking profitability in Mexico following the entry of foreign capital (Jan97-Sept02), using the Panzar and Rosse $H$-statistic. Their results indicate deterioration in competition in the banking system and a corresponding increase in the profitability of financial institutions as a result of the opening-up to foreign banks.

In the field of measurement of banking competition, other studies referring to emerging countries include Mexico in their samples. Thus, Gelos and Roldós (2004) find that their results are compatible with the existence of monopolistic competition in the period from 1994 to 1999, and that there was no change in the competition following the process of consolidation ${ }^{1}$.

In this context, the objective of the paper is to measure the degree of competition in the Mexican banking system in the period between 1993 and 2005, a longer period than that analyzed in previous studies and one that covers the processes of deregulation, liberalization and consolidation of the sector. For this we use two indicators taken from the so-called new empirical industrial organization: the Lerner index and the $H$-statistic.

In relation to other studies referring to the Mexican banking system, the novelties of this study are as follows. Firstly, the Lerner index is used for the first time in the Mexican banking system to measure the evolution of market power. The advantage of using it is that it permits the evolution of competition to be analyzed annually, and allows market power to be measured separately for the loans and deposits markets. Secondly, the analysis covers a period long enough to be able to observe whether the measures adopted (both privatization and opening-up to foreign investment) increased competition in the Mexican banking system. It has to be taken into account that studies carried out before now have analyzed only the consequences of privatization (Gruben and McComb, 2003) or the opening-up to foreign investment (Dueñas, 2003). And thirdly, banking competition is analyzed using two indicators (the $H$-statistic of Panzar and Rosse, and the Lerner index).

The results obtained permit us to conclude that the measures adopted and the transformations experienced by the Mexican banking system during recent years have not in general translated into greater competitive rivalry. Specifically, the results indicate that once the sale of the commercial banks to the private sector had been completed, the intensity of competition increased. Subsequently, the exchange rate crisis had an adverse effect on inflation and on interest rates, inducing an increase in

\footnotetext{
${ }^{1}$ However, this result is not robust as it uses 1997 as the start of the second sub-period and considers an unscaled revenue equation, since for these cases a decline in competition is found.
} 
market power in loans and deposits. Finally, once the restrictions on the entry of foreign capital had been completely eliminated in 1998, market power increased in deposits, while it decreased in the loans market, consolidating the following of a cross subsidization strategy. Consequently, it is possible that part of the recent growth of the profitability levels of the Mexican banking system is due to a decrease in competitive rivalry in the banking markets, which would permit us to call into question the efficacy of the measures so far implemented.

The structure of the rest of the paper is as follows. Section 2 describes the recent evolution of the Mexican banking system. Section 3 details the instruments used to measure banking competition. Section 4 specifies the variables and sample used, and presents the empirical results. Finally, section 5 presents the conclusions.

\section{The evolution of the Mexican banking system}

The Mexican commercial banking system was nationalized in 1982 in the context of a macroeconomic crisis. Fifty eight banks were nationalized, and only eighteen of these remained in 1990, when the process of privatization began. Specifically, privatization began with the reform of articles 28 and 123 of the constitution, so that the private sector once more had the possibility of participating in banking activities. The government sold its 18 banks in 14 months (June 91-July 92) at a high price compared to their book value (ratio: 3.49$)^{2}$.

López de Silanes and Zamarripa (1995) suggest that private financial groups paid high prices because they expected limited competition among banks. At that time the entry of foreign capital was not permitted. Haber (2005) defends another position, arguing that although bankers faced a risk of expropriation (since previously the government had already expropriated the banks) they accepted that price because much of the money that they risked was not their own, but came from Mexican small investors, commercial paper, foreign banks, other Mexican banks and in some cases the same bank that had been purchased.

With the privatization of the banking system, the public deficit was reduced, and with it the funding requirements of the public sector, enabling more resources of the

\footnotetext{
2 A detailed description of the process of privatisation of the Mexican banking system can be found in Gruben and McComb (1997 and 2003) and Haber (2005).
} 
banking system to be devoted to financing the private sector. Total loans to the private sector thus increased after the privatization and decreased following the crisis.

Throughout 1994 and particularly at the start of 1995, macroeconomic conditions deteriorated. Foreign investment, in particular portfolio investment, decreased, which given the high level of deficit of the balance of payments, occasioned the devaluation of the exchange rate. This collapse caused two problems in the Mexican banking system: on the one hand, since loans in dollars represented approximately a third of the total loans made by Mexican banks and many of them were taken out by firms without dollar revenue, the non-performing loans grew $156 \%$ in a single year, representing approximately $15 \%$ of the total loan portfolio (Source: Asociación de Banqueros Mexicanos). The peso value of their debts nearly doubled in the space of a few days once the exchange rate was allowed to float; in addition, foreign investors pulled their funds out of Mexico. Consequently the banks became insolvent, so the financial authorities of Mexico had to implement various programmes to prevent a banking crisis ${ }^{3}$.

One of the programmes implemented was the Temporary Capitalization Programme (PROCAPTE) aimed at guaranteeing in the Mexican banking system indices of capitalization of at least 8 per cent of assets with risk. The banks with a level of capitalization below the limit established issued convertible debentures that were acquired by the Fund for the Protection of Bank Savings (known by its Spanish acronym FOBAPROA, created in 1990). A special dollar credit window was also implemented since the majority of the banks had problems for the renewal of their credits in foreign currency.

Additionally, the programme of capitalization with purchase of portfolio was implemented for the following entities: BBV, Banca Serfín, Bancomer, Banamex, Banco del Atlántico, Banca Bital, Banca Promex, Bancrecer, Banorte, Banco Confía and Banco Mexicano.

Also, the commercial banks' portfolio of credits was restructured into Investment Units (UDIs). This unit of account reflects the behaviour of the consumer price index, so the amount of the credits denominated in the new currency remains constant in real terms. In this way, the banks transferred the credits that could be converted into UDIs to funds that they themselves managed. These funds, thanks to the loans granted by the government, converted the credits to the new currency; thus the

\footnotetext{
3 Haber (2005) points out that many of the Mexican banks already had problems before the crisis. The reason is that in Mexico institutions and property rights were weak.
} 
government assumed the interest rate risk, while the banks retained only the risk of default. In exchange, the commercial banks took up bonds issued by the government ${ }^{4}$.

The National Banking and Securities Commission (known by its Spanish acronym CNBV), through FOBAPROA, intervened in some banks with solvency problems and capitalized them; in others it only cleaned the bank's balance sheets of non-performing loans ${ }^{5}$. The total cost to the taxpayer associated with the bailout programs was $19.3 \%$ of the Gross Domestic Product (GDP).

For a long time the Mexican banking system was protected from foreign competition. With the signing of the North American Free Trade Agreement (NAFTA), a gradual opening-up to foreign investment was established. Foreign banks could not buy Mexican banks whose market share exceeded 1.5\%. Moreover, the total participation of foreign banks had to be less than $8 \%$, though this was gradually increased to a ceiling of $15 \%$. Subsequently, the laws were modified in 1995 with the aim of increasing the limits of foreign participation established in the NAFTA. The individual limit rose from $1.5 \%$ to $6 \%$ and the final aggregate limit of $15 \%$ to $25 \%$ (Murillo, 2002).

In December 1998, the Mexican Congress approved modifications to allow the foreign investment in Mexican banks to reach 100\%, thus permitting the largest banking institutions (Bancomer, Banamex and Serfin) to be acquired by foreign groups. As a consequence of the change in the rules, foreign investment entered the market, establishing new banks in Mexico or merging with Mexican banks. This led to foreign

\footnotetext{
4 Other debtor support programmes are: Agreement for Immediate Support to Bank Debtors (ADE), Complementary Programme of Support for Mortgage Credits, Programme of Support for the Agriculture Livestock and Fisheries Sector (FINAPE), Programme of Support for Medium, Small and Micro Firms (FOYME) and the "Full Stop" Programme. See Murillo (2002) for more detail on the programmes for the reorganisation of the banking system.

5 The CNBV implemented three schemes for the sale of banks with financial problems: sale of branches of the bank in question to commercial banks; whole or part sale of the bank to commercial banks; and part sale of the intervened bank to commercial banks with the option for the latter to subsequently increase their shareholding.
} 
participation rising from $5.5 \%$ in 1993 to $52.4 \%$ in 1996 and $67.2 \%$ in 2000 (see Murillo, 2002). Also, there were other reforms in the financial sector ${ }^{6}$.

The mergers and acquisitions caused an increase in market concentration, which had decreased following the privatization ${ }^{7}$ and the banking crisis. As can be observed in Figure 1, there is a downward trend from 1993 to 1996 and a subsequent increase from 1997 onwards. The participation of the three biggest banks (CR3) during 1993-2005 varies between $52 \%$ and $62 \%$.

FIGURE 1. Concentration of the Mexican banking markets

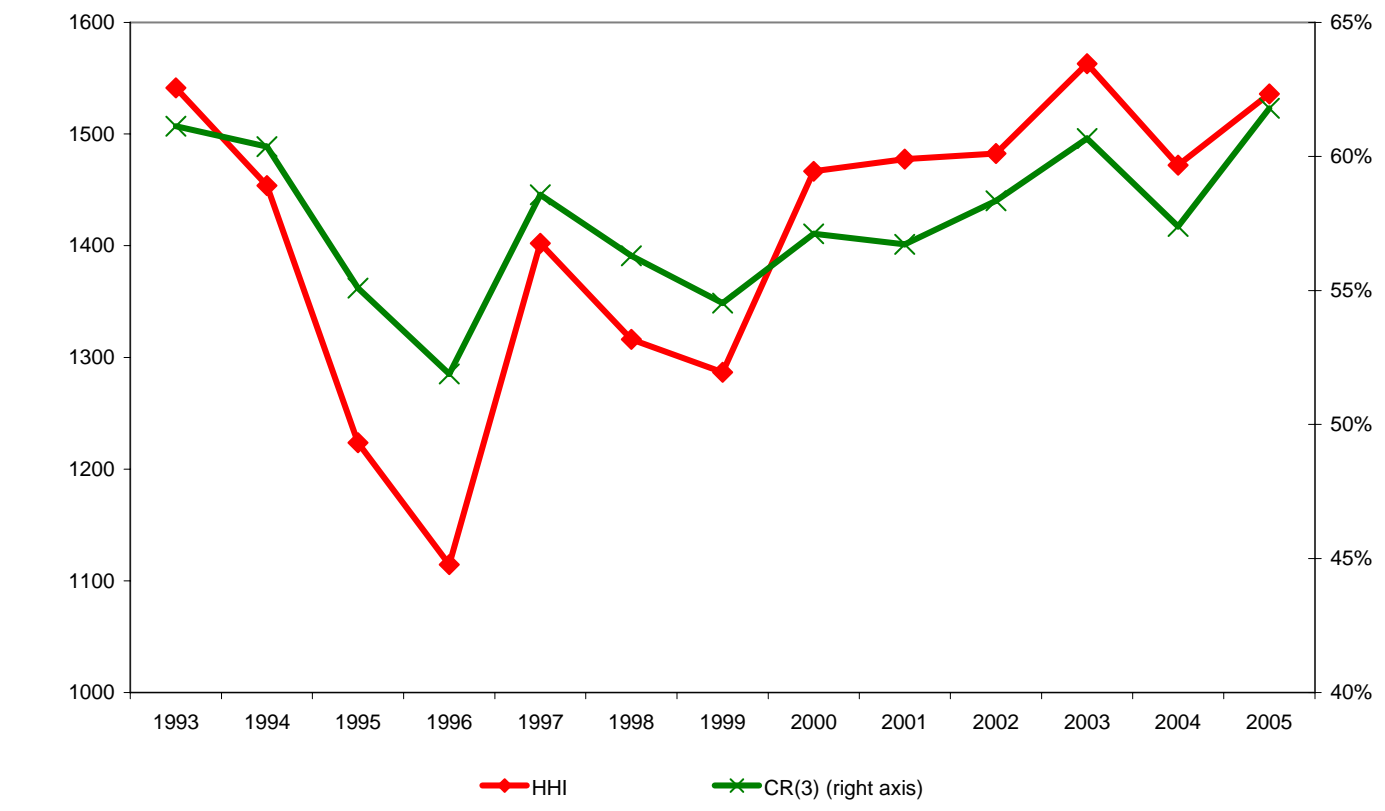

Source: Calculations were made using data from Comisión Nacional Bancaria y de Valores.

In order to analyze the effect of the changes described above on the behaviour of the Mexican banking system, it is of interest to analyze the evolution of costs, banking margins and profitability in the period analyzed. In the first case, the high personnel

\footnotetext{
${ }^{6}$ In 1997 new accounting criteria and rules were implemented, relating mainly to the recognition of inflation in the financial statements of banks, very similar to international norms. In 1998, the Law on Protection of Bank Savings was passed, establishing the Institute for the Protection of Bank Savings (IPAB). New criteria were issued for calculating the capital requirements of financial institutions, consistent with international standards, as well as new accounting principles and rules relating to greater financial transparency of banking institutions. In 2000 the Law on Protection and Defence of Users of Financial Services and the Mexican Commercial Insolvency Law were passed, aimed at regulating the relationship between debtors and creditors, among others.

${ }^{7}$ Mexico began to open its markets to new domestic entrants in 1993, and in 1995 the operation of 13 new foreign subsidiaries was authorised.
} 
costs, and those necessary to endow the banks with advanced technology, heavily influence the increase in average operating costs from 1997 to 2000, although consolidation has translated into increased labour efficiency, with the number of staff being reduced by more than $10 \%$ between 1997 and 2000. Nevertheless, the increase in margins permitted the rise in average costs to be absorbed, thus improving operating efficiency (Figure 2).

\section{FIGURE 2. Average operating costs and efficiency of the Mexican banking system}

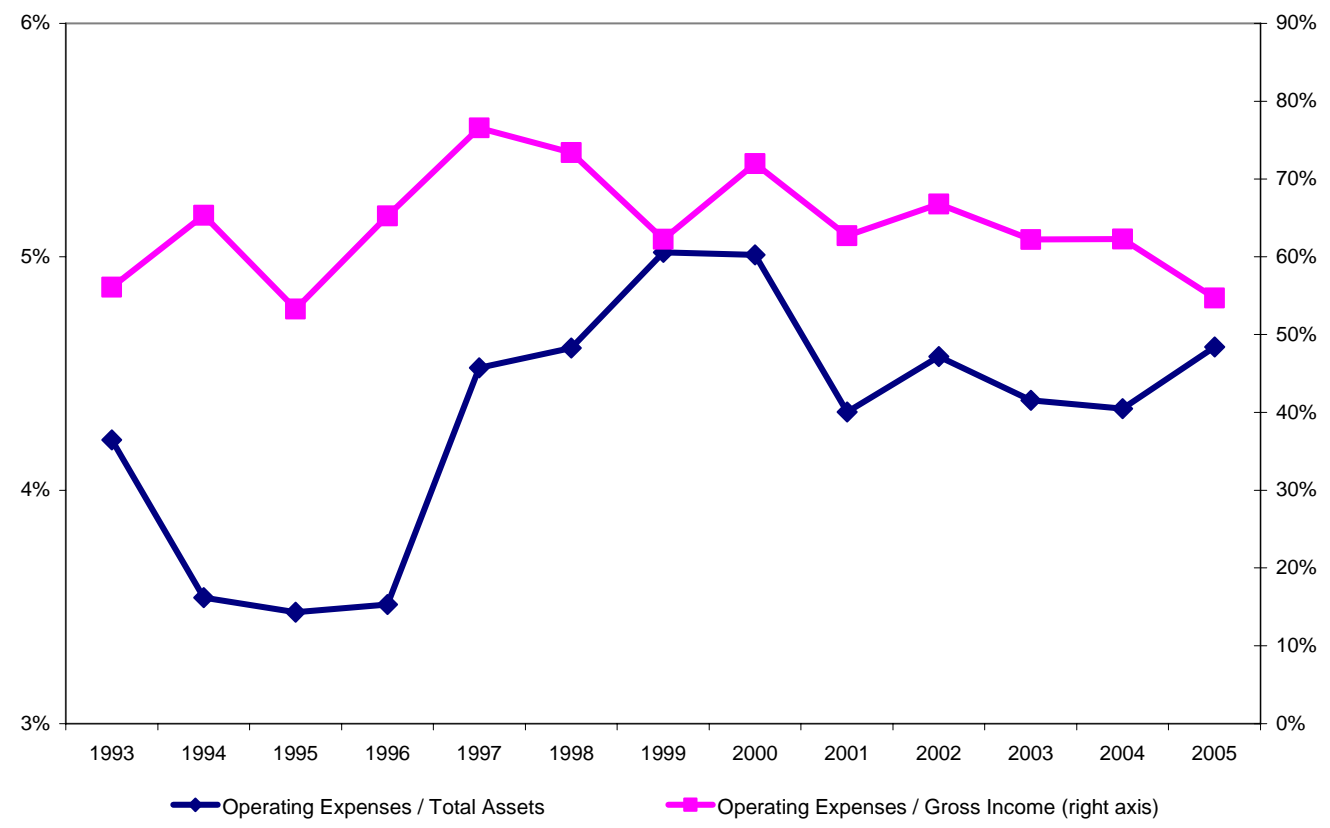

Source: Own elaboration with data from Comisión Nacional Bancaria y de Valores.

In the case of banking margins, the Mexican banking system is characterized by its high margins. In the years following privatization (or prior to the crisis of the peso), the Mexican commercial banks experienced a reduction in margins and an increase in non-performing loans, in spite of the fall in operating expenses (see Figure 2). The net effect of the evolution of margins and operating costs is a deterioration in profitability, reaching a negative value in 1996 (see Figure 3). Subsequently, an increase in margins is observed in 1998 due to the rise in the price of money (Figure 3$)^{8}$.

Once the banking system had recovered from the crisis, profitability showed an increasing trend, reaching a maximum value in 2005. This increase was due, firstly, to the increase in gross income as a consequence of the growth of fees and commissions

\footnotetext{
${ }^{8}$ As shown by the model of Ho and Saunders (1981), banking margins depend positively on the volatility of interest rates.
} 
(from $1.1 \%$ to $2 \%$ of total assets) ${ }^{9}$, though financial revenue decreased from 2000 onwards, in part as a result of the low levels of lending (a slight reduction being observed in net interest income). At the end of the period analyzed (2004-2005), we continue to observe a tendency for the interest margin to increase, propitiated by a context of rising interest rates (see Figure 3). Second, the non-performing loans decreased considerably, reaching $5.8 \%$ and $1.8 \%$ of the total credit portfolio in 2000 and 2005 , respectively.

\section{FIGURE 3. Margins and profitability}

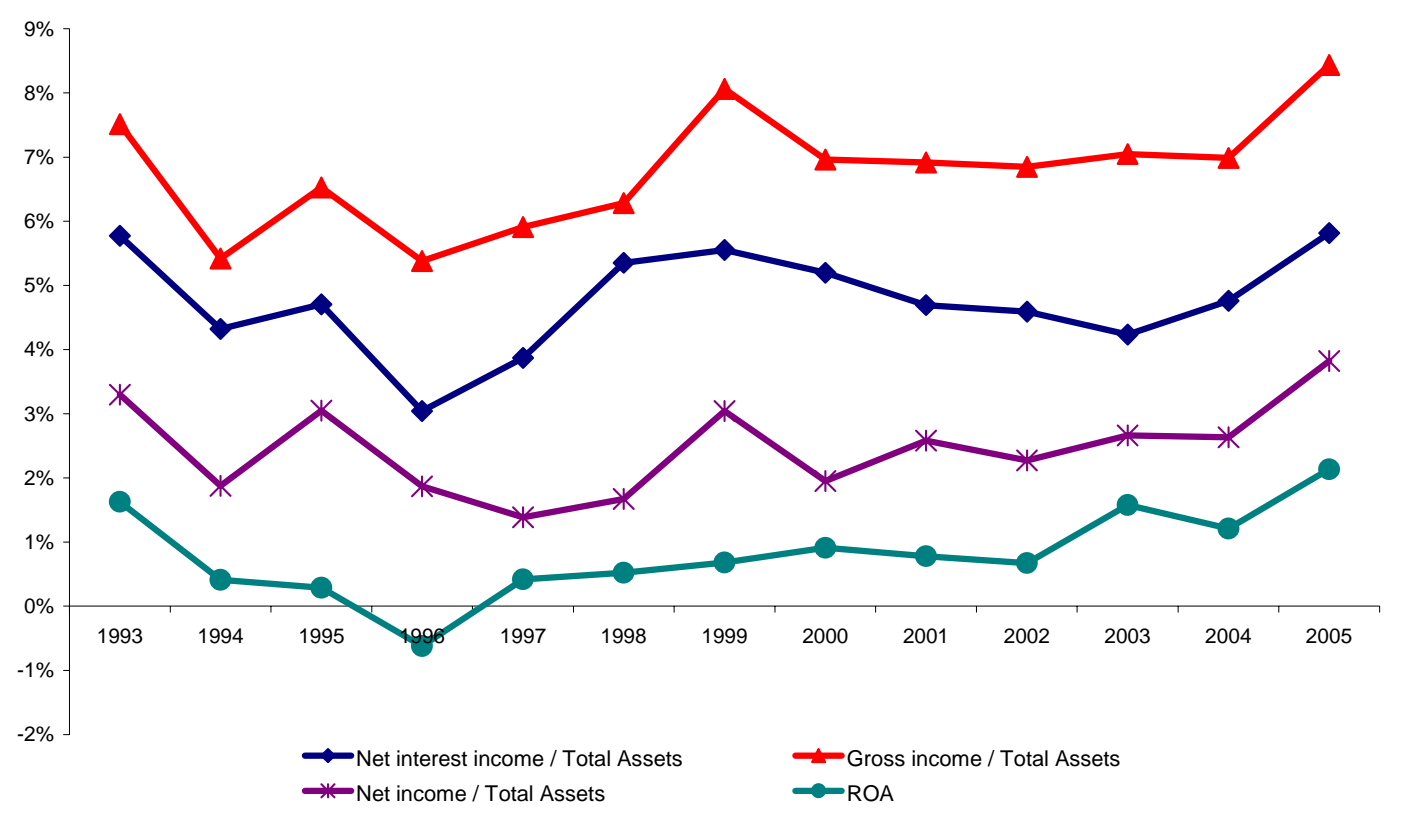

Source: Own elaboration with data from Comisión Nacional Bancaria y de Valores.

The overall view of the recent behaviour of the efficiency and the profitability of the Mexican banking system shows that gains in efficiency may have translated into extraordinary profits for the banks and not necessarily into benefits for the rest of the economy. As the Governor of the Bank of Mexico has recently affirmed ${ }^{10}$, this situation points to the existence of an uncompetitive banking system with high margins that prevents the economy from attaining the rates of growth that the gains in efficiency

${ }^{9}$ Net commissions have been a very important source of revenue in the commercial banking system, which have increased and are the second most important source of revenue after the net interest income margin.

10 The words of Dr. Guillermo Ortiz, Governor of the Bank of Mexico, at the $69^{\text {th }}$ banking convention held in Acapulco, Gro., March 24th 2006. (http://www.banxico.gob.mx/gPublicaciones/ SPublicaciones.html ). 
would have permitted. Consequently, it is of great importance to evaluate the intensity of competition in financial services.

\section{The measurement of banking competition}

The instruments for measuring banking competition can be classified into two groups. The first includes the use of structural indicators (market concentration) and the estimation of the well-known Structure-Conduct-Performance (SCP) vs. the efficient structure hypothesis. The second approach, known as New Economics of Empirical Industrial Organization, includes the $H$-statistic of Panzar and Rosse (1987) and the Lerner index of market power. Of the two groups of instruments, this paper focuses on the second, since they are indicators of competition derived from problems of banking optimization, and therefore present a solid theoretical basis.

\subsection{Panzar and Rosse's H-Statistic}

The essence of the Panzar and Rosse test is to analyze the elasticity of revenue to variations in the prices of the factors of production, by estimating a reduced revenue equation. Specifically, Panzar and Rosse (1987) show that the sum of the revenue elasticities of a firm, relative to the price of its inputs (habitually known as the $\mathrm{H}$ statistic) provides an evaluation of the competitive structure of a market. It is important to point out that the validity of the test depends crucially on being in a situation of long term equilibrium, where rates of return should not be correlated statistically with input prices.

Let $R$ be the reduced form of a revenue function that depends on the price of inputs $(w)$ and exogenous variables $(z)$ :

$$
R=R(w, z)
$$

The $H$ - statistic is defined as:

$$
H=\sum \frac{\partial R}{\partial w_{i}} \frac{w_{i}}{R_{i}}
$$

Panzar and Rosse demonstrate that the $H$-statistic is non-positive for monopoly, collusive oligopoly or conjectural variation oligopoly; equal to unity for perfect competition; and between 0 and 1 for monopolistic competition. 
In empirical applications, the rejection of the null hypothesis that $\mathrm{H} \leq 0$ eliminates the possibility that a monopoly exists. Rejection of the null hypothesis that $\mathrm{H} \leq 1 \mathrm{implies}$ rejection of the three models, while rejection of both hypotheses $(\mathrm{H} \leq 0$ and $\mathrm{H}=1$, but not $\mathrm{H} \leq 1$ ) implies that only monopolistic competition is consistent with the data. As mentioned above, the validity of the test requires the condition of long term equilibrium. A simple way to test this condition is to replace the dependent variable by ROA in equation (3), so that if the sum of the elasticities of the inputs prices is not statistically different from zero the existence of long term equilibrium cannot be rejected.

One way of estimating the $\mathrm{H}$-statistic is by using a log-linear regression of the revenue function, the dependent variable being the ratio of interest revenues to total $\operatorname{assets}^{11}$ :

$$
\ln \left(P_{i t}\right)=\alpha+\sum_{J=1}^{3} \beta_{j} \ln w_{i t}^{J}+\sum_{k=1}^{3} \gamma_{j} \ln E_{i t}^{k}+\varepsilon_{i t}
$$

for $t=1, \ldots, T$, where $T$ is the number of periods observed and $i=1, \ldots, I$, where $I$ is the total number of banks. Subscripts $i$ and $t$ refer therefore to bank $i$ at time $t$. $P$ denotes the ratio of interest revenues to total assets, $w$ is the price of the factors of production (labour, lendable funds and physical capital), and $E_{i t}{ }^{k}$ are bank-specific control variables. Specifically, $E_{i t}{ }^{1}$ are the net loans as a proportion of total assets, $E_{i t}{ }^{2}$ the deposits as a proportion of total assets and $E_{i t}{ }^{3}$ is the ratio of equity to total assets which captures the leverage reflecting differences in the risk preferences across banks.

This instrument for measuring competition is used in various studies: Nathan and Neave (1989) for the Canadian financial system; Molyneux et al. (1994) for 12 European countries; Shaffer (2002 and 2004) for a bank that has a monopoly in Kent County, Texas; and for four banks: two in Texas and two in Kentucky, respectively; Carbó et al. (2003a, b and c) use the test to measure competition in the Spanish banking system; Gelos and Roldós (2004) for emerging countries from 1994 to 1999 (including Mexico); and Claessens and Laeven (2004) for 50 countries (including Mexico). For the case of Mexico, Dueñas (2003) uses the test for the period between Jan97 and Sep02.

\footnotetext{
${ }^{11}$ Here we follow the specification of Bikker and Haaf (2002), Claessens and Laeven (2004), and Gelos and Roldós (2004). Robust results are obtained by using unscaled revenues as the dependent variable in equation (3).
} 


\subsection{Lerner Index}

The model most widely used to calculate the Lerner index of market power in the specific case of banking firms is the Monti-Klein model. This model analyses the behavior of a monopolistic bank that is facing a demand curve for loans with a negative slope $L\left(r_{L}\right)$ and a supply of deposits with a positive slope $D\left(r_{D}\right)$. The decision-making variables are the quantity of the loans $(L)$ and the quantity of the deposits $(D)$. These variables influence their interest rates ( $r_{L}$ and $r_{D}$, respectively) and their level of capital is taken as given. Another case considered in this model is that the bank is price -taker in the inter-bank market $(r)$.

The profit of bank $\pi$ is the sum of the intermediation margins of loans and deposits minus operating costs $(C)$.

$$
\pi=\pi(L, D)=\left(r_{L}-r\right) L+\left(r-r_{D}\right) D-C(D, L)
$$

Given a value of the elasticities of the demand for loans $\varepsilon_{L}$ and of the supply of deposits $\varepsilon_{D}$, the first order conditions of the problem of optimization are as follows:

$$
\begin{aligned}
& \frac{r_{L}^{*}-r-m c_{L}}{r_{L}^{*}}=\frac{1}{\varepsilon_{L}\left(r_{L}^{*}\right)} \\
& \frac{r-r_{D}^{*}-m c_{D}}{r_{D}^{*}}=\frac{1}{\varepsilon_{D}\left(r_{D}^{*}\right)}
\end{aligned}
$$

Equations (5) are simply the adaptation to the banking sector of the equalities between the Lerner index (price minus marginal cost $-m c$ - divided by the price) and the inverse elasticity. We observe that the lower the elasticity the greater the intermediation margin, i.e. the greater the Lerner index of market power.

As shown by Freixas and Rochet (1997), it is possible to reinterpret the MontiKlein model as a model of imperfect competition (Cournot) among a finite number $(\mathrm{N})$ of banks. In this case, the Cournot equilibrium of the banking sector is an N-tuple of vectors $\left(D_{n}^{*}, L_{n}^{*}\right)_{n=1, \ldots N}$, such that for every $n$, each bank maximizes its profit given the volume of deposits and of loans of the other banks:

$$
\max _{D_{n}, L_{n}}\left[r_{L}\left(L_{n}+\sum_{m \neq n} L_{m}\right)-r\right] L_{n}+\left[r-r_{D}\left(D_{n}+\sum_{m \neq n} D_{m}\right)\right] D_{n}-C\left(D_{n}, L_{n}\right)
$$


so that there is a single equilibrium where each bank sets $L_{n}=\frac{L}{n}$ and $D_{n}=\frac{D}{n}$.

From the first order conditions of the optimization problem (6) we obtain:

$\frac{\left[r_{L}^{*}-r-m c_{L}\right]}{r_{L}^{*}}=\frac{1}{N \varepsilon_{L}\left(r_{L}^{*}\right)} \quad \frac{\left[r-r_{D}^{*}-m c_{D}\right]}{r_{D}^{*}}=\frac{1}{N \varepsilon_{D}\left(r_{D}^{*}\right)}$

when $\mathrm{N}=1$, it represents the case of a monopoly and when $\mathrm{N}=\infty$ it is perfect competition.

The estimation of the Lerner index has been applied, among others, in the studies by Angelini and Cetorelli (2003) for the Italian banking sector; Maudos and Pérez (2003) and Carbó et al. (2003a and b) for the Spanish banking sector; Fernández de Guevara et al. (2005) for the case of five European countries; and Maudos and Fernández de Guevara (2007) for 15 European countries.

\section{Empirical approach and results}

\subsection{Variables, sample and empirical approach}

The sample used is formed by an unbalanced panel data from 303 annual observations corresponding to 47 commercial banks for the period between 1993 and 2005, which represent an average $94 \%$ of the total assets of the Mexican commercial banking system during the period of study ${ }^{12}$. The data is obtained from the Statistical Bulletin of the Multiple Banking system of the National Banking and Securities Commission and from the Basic Banking Information System of the Bank of Mexico.

Given the unavailability of information on interest rates at bank level, these are estimated as the ratio of financial revenues (costs) to the volume of loans (deposits). Thus the problems of availability of data oblige us to work with average interest rates instead of marginal rates.

12 Observations whose information is of doubtful reliability, and banks that did not report information for some of the variables necessary for estimating the indicators of competition, were eliminated from the sample. 
The variables used in the estimation of the $H$-statistic and the Lerner index are as follows:

a) Price of labour $\left(w_{1}\right)$, obtained as the ratio of personnel expenditure to the number of workers.

b) Price of lendable funds $\left(w_{2}\right)$, proxied as the ratio of financial costs to deposits.

c) Price of physical capital $\left(w_{3}\right)$, proxied as the ratio of operating expenses other than personnel costs to fixed assets.

d) Interest rate on loans $\left(r_{L}\right)$, calculated as the ratio of financial revenue to the value of loans.

e) Interest rate on deposits $\left(r_{D}\right)$, calculated as the ratio of financial costs to the volume of deposits. Observe that by construction $r_{D}$ is equal to the price of lendable funds $w_{2}$.

f) Money market interest rate $(r)$, calculated as the annual average of the inter-bank interest rate (TIIE) at 28 days ${ }^{13}$.

Given the availability of a panel data, the estimation of revenue function (3) includes individual fixed effects in order to capture the influence of specific variables of each bank and time effects that capture the influence of factors common to all the banks and specific to the different years of the period analyzed.

The Lerner index is estimated separately for loans and deposits, according to expressions (7). Likewise, marginal operating costs are estimated separately for loans and deposits on the basis of the estimation of a translogarithmic cost function:

$$
\begin{aligned}
\ln c_{i t}= & \sum \gamma_{h} \ln w_{h i t}+\gamma_{L} \ln L_{i t}+\gamma_{D} \ln D_{i t}+\frac{1}{2} \sum \sum \gamma_{h m} \ln w_{h i t} \ln w_{m i t}+\gamma_{L D} \ln L_{i t} \ln D_{i t} \\
& +\frac{1}{2} \gamma_{L L}\left(\ln L_{i t}\right)^{2}+\frac{1}{2} \gamma_{D D}\left(\ln D_{i t}\right)^{2}+\sum \gamma_{h L} \ln L_{i t} \ln w_{h i t}+\sum \gamma_{h D} \ln D_{i t} \ln w_{h i t} \\
& +\mu_{1} T+\frac{1}{2} \mu_{2} T^{2}+\mu_{L} T \ln L_{i t}+\mu_{D} T \ln D_{i t}+\sum \mu_{h} T \ln w_{h i t}+u_{i t}
\end{aligned}
$$

where $c$ are the operating costs, $w$ the prices of the two inputs (labour and capital), $L$ the loans and $D$ the deposits, $T$ is a trend that captures the effect of technical progress. The

\footnotetext{
13 The results are robust if we use the annual average of the interest rate on Federation Treasury Certificates (CETES).
} 
restrictions of symmetry and grade one homogeneity in input prices are imposed in the estimation. As with the estimation of the revenue function, the estimation of the cost function includes individual fixed effects.

On the basis of the estimation of equation (8), marginal operating costs are calculated for loans and deposits for each bank and year of the period analyzed according to the following equations:

$$
\begin{aligned}
& m c_{L_{i t}}=\frac{\partial c_{i t}}{\partial L_{i t}}=\left[\gamma_{L}+\gamma_{L L} \ln L_{i t}+\sum \gamma_{h L} \ln w_{h i t}+\gamma_{L D} \ln D_{i t}+\mu_{L} \text { Trend }\right] \frac{c_{i t}}{L_{i t}} \\
& m c_{D_{i t}}=\frac{\partial c_{i t}}{\partial D_{i t}}=\left[\gamma_{D}+\gamma_{D D} \ln D_{i t}+\sum \gamma_{h D} \ln w_{h i t}+\gamma_{L D} \ln L_{i t}+\mu_{D} \text { Trend }\right] \frac{c_{i t}}{D_{i t}}
\end{aligned}
$$

In addition, with the aim of comparing the results obtained with the two indicators of competition (Lerner index and $\mathrm{H}$-statistic) it is of interest to calculate a joint or aggregate Lerner index of banking activity. For this we follow the approach used in Maudos and Fernández de Guevara (2004) and Fernández de Guevara et al. (2005 and 2007) who proxy banking production by means of total assets. The joint Lerner index for the total banking activity is thus estimated as follows:

$$
L_{T A}=\frac{r_{T A}-m c_{T A}}{r_{T A}}
$$

where $r_{T A}$ is the average price of banking activity (proxied as the ratio of banking revenue and total assets), and $m c_{T A}$ is the total marginal cost (operating + financial). This last is estimated from a translog total cost function with one output (total assets) and 3 inputs (labour, physical capital and lendable funds).

\subsection{Results}

\subsubsection{Panzar and Rosse's H- Statistic}

Table 1 shows the results of the estimation of the revenue function and the $H$ statistic. The value of the $H$-statistic (0.50) is statistically greater than zero and less than one at $1 \%$ significance, reflecting the existence of market power compatible with a situation of monopolistic competition. This result is consistent with that obtained by Dueñas (2003) for the period between 1997 and September 2002, Claessens and Laeven (2004) for the period 1994 to 2001 and Gelos and Roldós (2004) from 1994 to 1999. 
TABLE 1. $H$-statistic

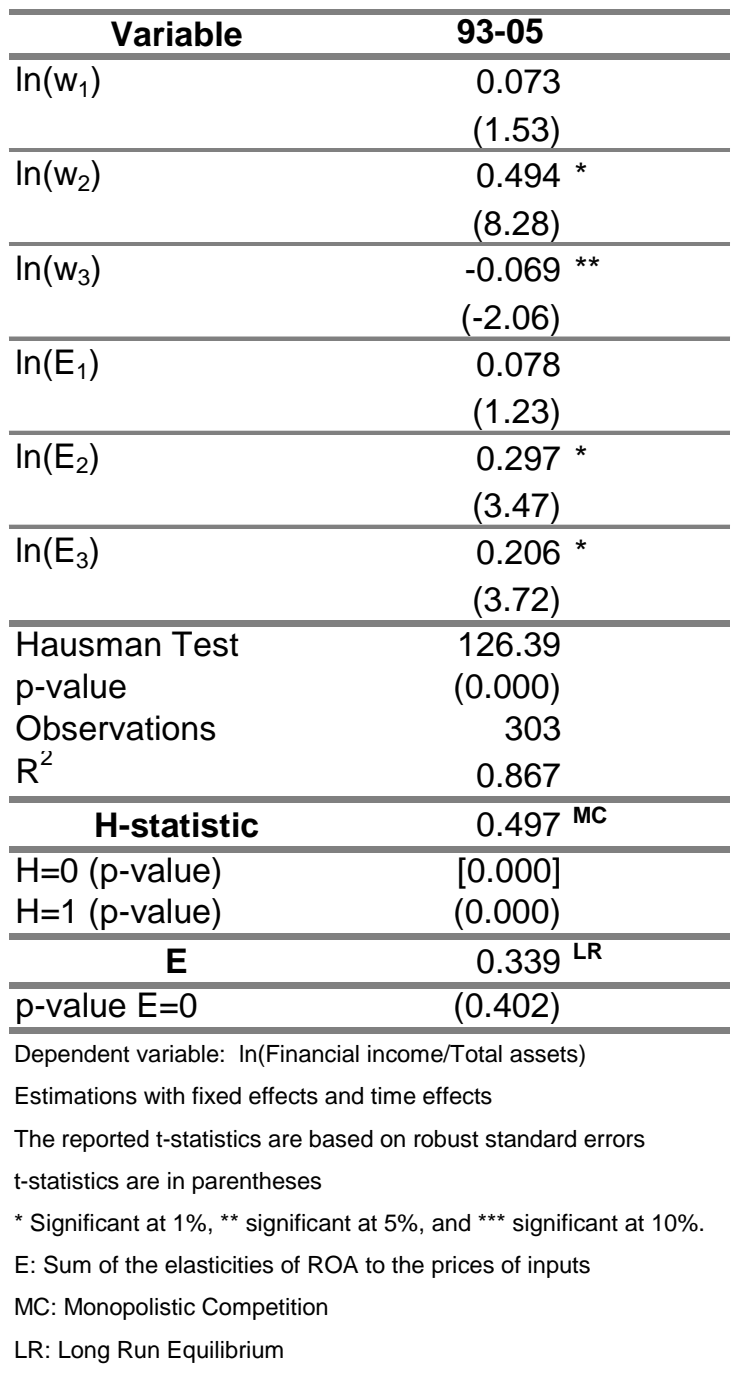

As commented earlier, the validity of the test requires the existence of long term equilibrium. For this, following Molyneux et al. (1994) and Claessens and Laeven (2004), we re-estimate equation (3) replacing the dependent variable by the return on assets (ROA). As Table 1 shows, it is not possible to reject the hypothesis that the sum of the elasticities of ROA to the prices of inputs is equal to zero, so the condition of long term equilibrium is guaranteed. Nevertheless, since the period analyzed is a period of major transformations in the Mexican banking system, this "equilibrium" result does not mean that competitive conditions are not allowed to change, it only implies that changes in banking are taken as gradual (see De Bandt and Davis, 1999; and Drakos and Konstantinou, 2005). 


\subsubsection{Lerner Index}

Figure 4 shows the evolution of the Lerner index and of its determining factors. In the case of the interest rates on loans and deposits, the evolution is in turn determined by the behaviour of the inflation rate, with a steep rise until 1995 and a fall thereafter ${ }^{14}$. The differential between the interest rate on loans and the inter-bank interest rate $\left(r_{L}-r\right)$ increases from 1993-95, decreases from 1996-98, and is practically nil from then onwards ${ }^{15}$. On the liabilities side, the spread $\left(r-r_{D}\right)$ is always positive and decreases in the sub-periods 1996-97 and 2000-03, as can be observed in Figure 4. The marginal operating cost of loans increased from 0.025 in 1993 to 0.032 in 2005 , while the marginal operating cost of deposits decreased from 0.028 in 1993 to 0.026 in 2005.

In the case of absolute margins (numerator of the Lerner index), the temporal evolution is very different in loans and in deposits. Thus, the absolute margin of loans is positive only in 1995 and 1996, grows from 1993 to 1995, decreases in the sub-period 1996-98, and remains relatively stable until the end of the period analyzed. The absolute margin on deposits, on the other hand, is always positive from 1994 onwards. Absolute margins, both on loans and on deposits, reach their maximum value in 1995 as a consequence of the high inflation rate in that year.

The decomposition in the period analyzed of the change in the absolute margin on loans into a spread with respect to the inter-bank interest rate $\left(r_{L}-r\right)$, minus the change in the marginal cost, indicates that the increase of 0.16 percentage points (p.p.) in the absolute margin is due to an increase in the spread of 0.85 p.p. and to an increase of 0.69 p.p. in the marginal cost. In the case of deposits, the spread $\left(r-r_{D}\right)$ increased 4.55 p.p. and the marginal cost fell 0.18 p.p. so the absolute margin increased 4.73 p.p. Consequently, the change in the absolute margin, in both loan and deposit markets, is due more to the change in the spread with respect to the inter-bank interest rates than to the change in marginal costs.

In terms of relative margins, market power increased in the deposits market while it decreased in that of loans. This conclusion arises from (Figure 4). In the subperiod 1993-97, the evolution of Lerner indices in the loans and deposits markets is

\footnotetext{
14 The evolution of asset and liability interest rates calculated with data at bank level using the information from the CNBV is similar to the aggregate interest rates reported by the Bank of Mexico [commercial paper weighted average interest rate and 2 month fixed term deposits opening rate (rate before tax)].

15 It is important to point out that $r_{L}$ represents an average interest rate on loans. However, there may exist some financial products where this relationship does not hold. Unfortunately, it is not possible to make a more disaggregated study due to the lack of information.
} 


\section{FIGURE 4. The evolution of the Lerner index}

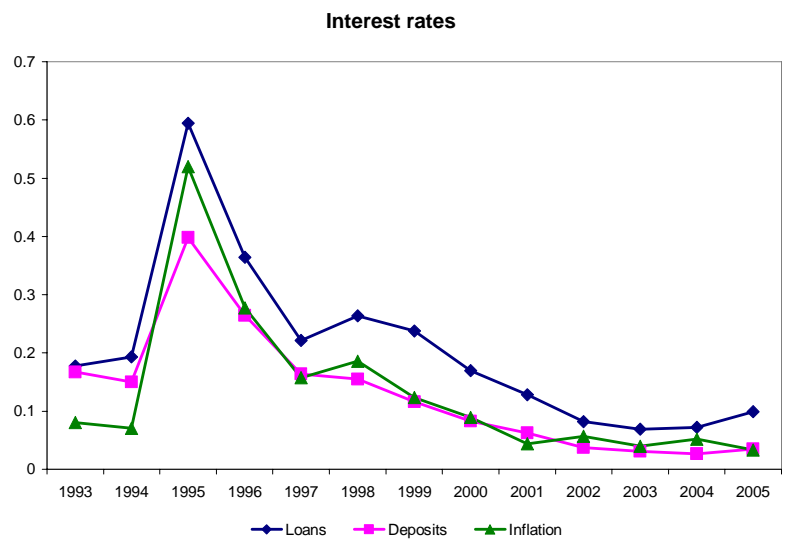

Source: Own elaboration based on data from Comisión Nacional Bancaria y de Valores and Banco de México.

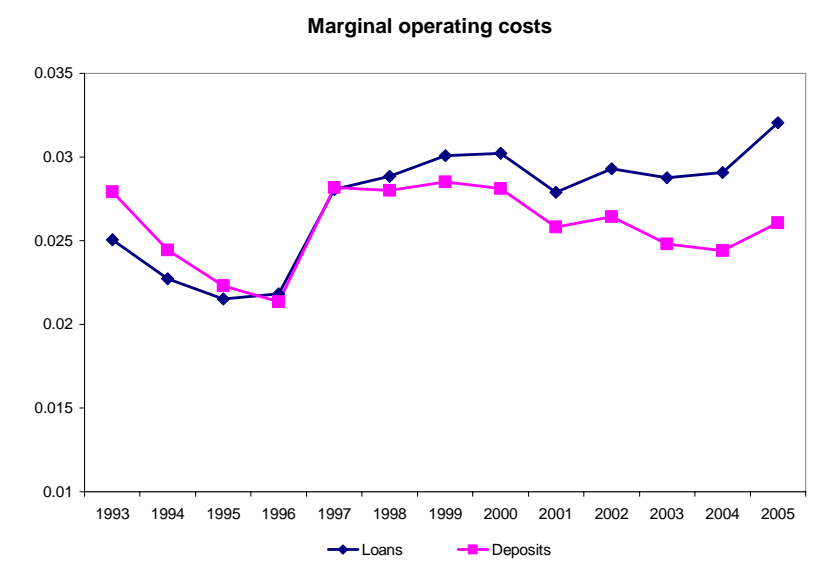

Source: Own elaboration based on data from Comisión Nacional Bancaria y de Valores and Banco de México.

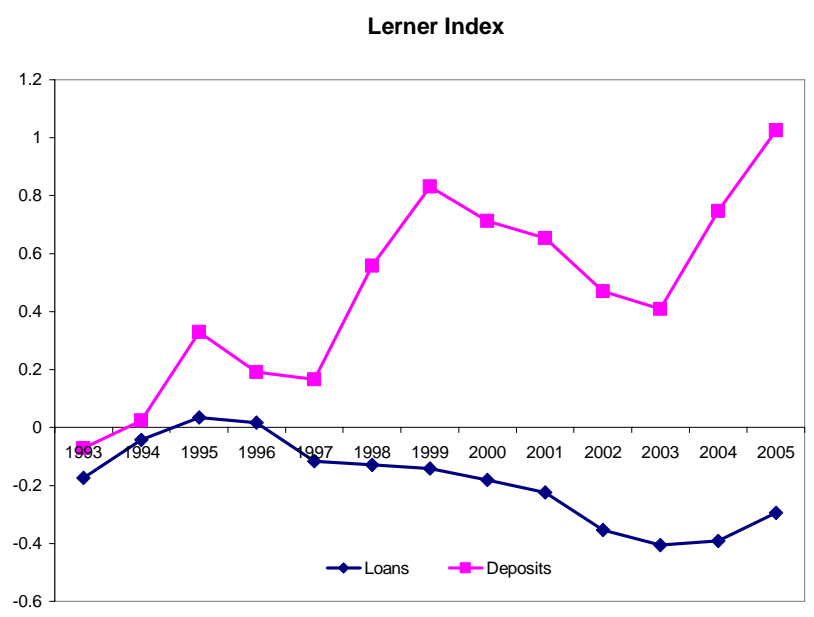

Source: Own elaboration based on data from Comisión Nacional Bancaria y de Valores and Banco de México.

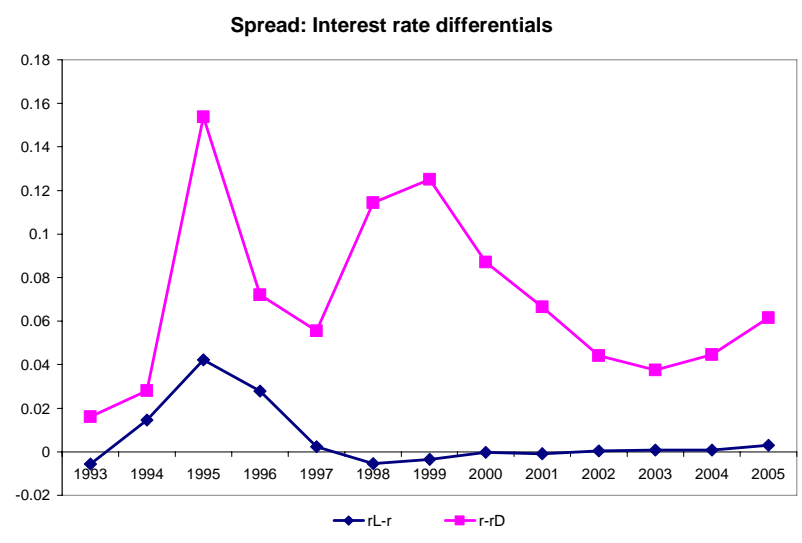

Source: Own elaboration based on data from Comisión Nacional Bancaria y de Valores and Banco de México.

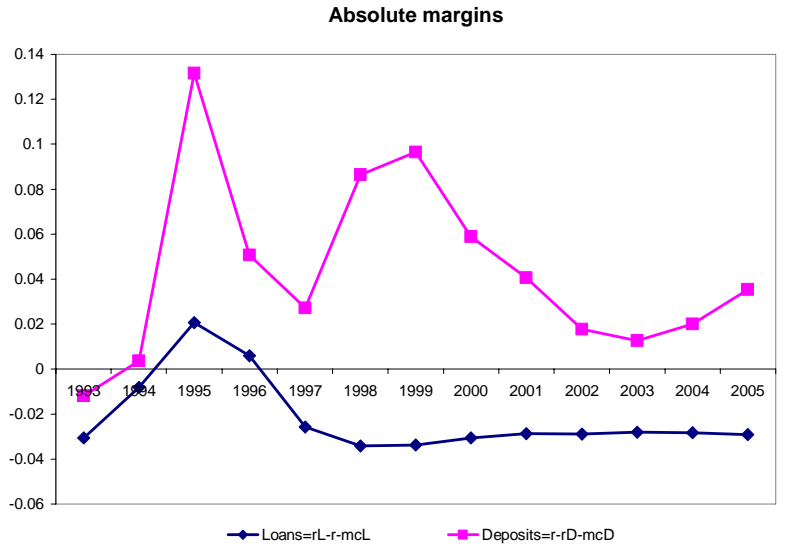

Source: Own elaboration based on data from Comisión Nacional Bancaria y de Valores and Banco de México. 
similar, rising 1993-95 and falling until 1997. From that year onwards, the evolution is different for the two relevant markets. Thus, in deposits (loans), market power increases (decreases) until 1999 (2003) and then decreases until 2003. Finally, in both banking markets the Lerner index again rises from 2003 to 2005.

One notable feature is that, from 1997 to 2005, cross-subsidies exist in the services offered by Mexican banks, as they grant loans with very small and even negative margins with the aim of attracting or keeping clients, recuperating this loss by setting higher margins in the deposits market ${ }^{16}$.

With the aim of analyzing whether the variation of the Lerner index responds more to the variation of margins relative to the inter-bank interest rate or relative to marginal costs, it is of interest to decompose the variation of the Lerner index as follows:

$$
\begin{aligned}
& \Delta \text { Lerner }_{L}=\Delta\left(\frac{r_{L}-r}{r_{L}}\right)-\Delta\left(\frac{m c_{L}}{r_{L}}\right) \\
& \Delta \text { Lerner }_{D}=\Delta\left(\frac{r-r_{D}}{r_{D}}\right)-\Delta\left(\frac{m c_{D}}{r_{D}}\right)
\end{aligned}
$$

On the basis of this decomposition, for the entire period analyzed, the decrease in 12.09 p.p in the Lerner index in loans is due to an increase of 6.13 p.p. of the ratio of the spread $\left(r_{L}-r\right)$ to the interest rate on loans and to an increase of 18.22 p.p. in the ratio of marginal cost to interest rate on loans. In the case of deposits (which increased by 109.66 p.p.), the ratio of the spread $\left(r-r_{D}\right)$ to the rate of interest on deposits increased by 168.33 p.p., while their marginal operating cost increased by 58.67 p.p. In consequence, the above decomposition shows that, as in the absolute margin, the variation of the Lerner index in deposits is due more to the changes in inter-bank margins than to changes in marginal costs, while in the loan market, the variation of the Lerner index is due in greater measure to the change in marginal costs ${ }^{17}$.

Following the privatization of the Mexican banking system in 1991 and 1992, it can be observed that market power is negative in the loan market as a consequence of the strong growth of bank credit, the loans/GDP ratio rising from $19.9 \%$ in 1991 to

\footnotetext{
16 This result is in line with those obtained by Carbó et al. (2005) and Maudos and Fernández de Guevara (2007) who find evidence of the existence of a loss-leader strategy in the European banking sectors.

17 This result is in concordance with the view arising from Figure 4, which shows a differential $r_{L}-r$ relatively stable and nil from 1997 onwards.
} 
$32.8 \%$ in 1995 , thus increasing credit risk ${ }^{18}$. Since the banks incurred high risks, the ratio of non-performing loans to total credit rose from $7.7 \%$ in 1995 to $11.3 \%$ in 1998 .

After the crisis, there was a period of restructuring and beginning to consolidate the Mexican banking system (with gradual opening-up to foreign investment), producing a severe contraction of credit (the loans/GDP ratio fell from $27.6 \%$ in 1996 to $19.7 \%$ in 1999 , and non-performing loans decreased to $8.9 \%$ of the total credit portfolio in 1999). In this period market power in loans was reduced. Finally, once restrictions on foreign investment were totally removed and the most important banks were acquired by foreign groups, market power in loans was reduced by $11.35 \%$ from 2000 to 2005 .

It is important to point out that given the low and even nil margins with which banks operate in the loans market, it is logical that there should have occurred a decrease in the relative importance of financial revenue and an increase in activity with repos. Thus, the ratio of revenue from repos to financial revenue increased from $7.8 \%$ in 1993 to $27.8 \%$ in 2005 .

In the case of deposits, the results show that the banks pay a very low premium for the capture of resources, obtaining a high differential over the inter-bank interest rate (see Figure 4). Furthermore, in the period analyzed, competition in the deposits market is observed to decrease ${ }^{19}$.

In terms of total banking activity, Figure 5 shows the evolution of the Lerner index for total assets. A decrease in market power is observed from 1993 to 1996; it is negative during the crisis and the years of recovery. On the other hand, from 1998 the Lerner index of market power in banking activity as a whole increased substantially, tripling its value to reach the highest value of the index in 2005. This result, as well as demonstrating an increase in the market power of the Mexican banking system, shows that the cross subsidization strategy is highly profitable for the banks. In fact, the levels of profitability (ROA) of the Mexican banking sector have increased substantially since 1998 (see Figure 3).

The evolution of the Lerner index shows that the changes undergone by the Mexican banking system in recent years have had diverse effects on market power. Thus, the results allow us to conclude that, once the sale of the commercial banks to the

18 Since the deposits were guaranteed by the FOBAPROA, the banks incurring a higher credit risk aggravating the problems of moral hazard.

19 The variations in the Lerner index for deposits can be explained to a greater extent by changes in margins relative to the inter-bank interest rate than by changes in marginal costs. 


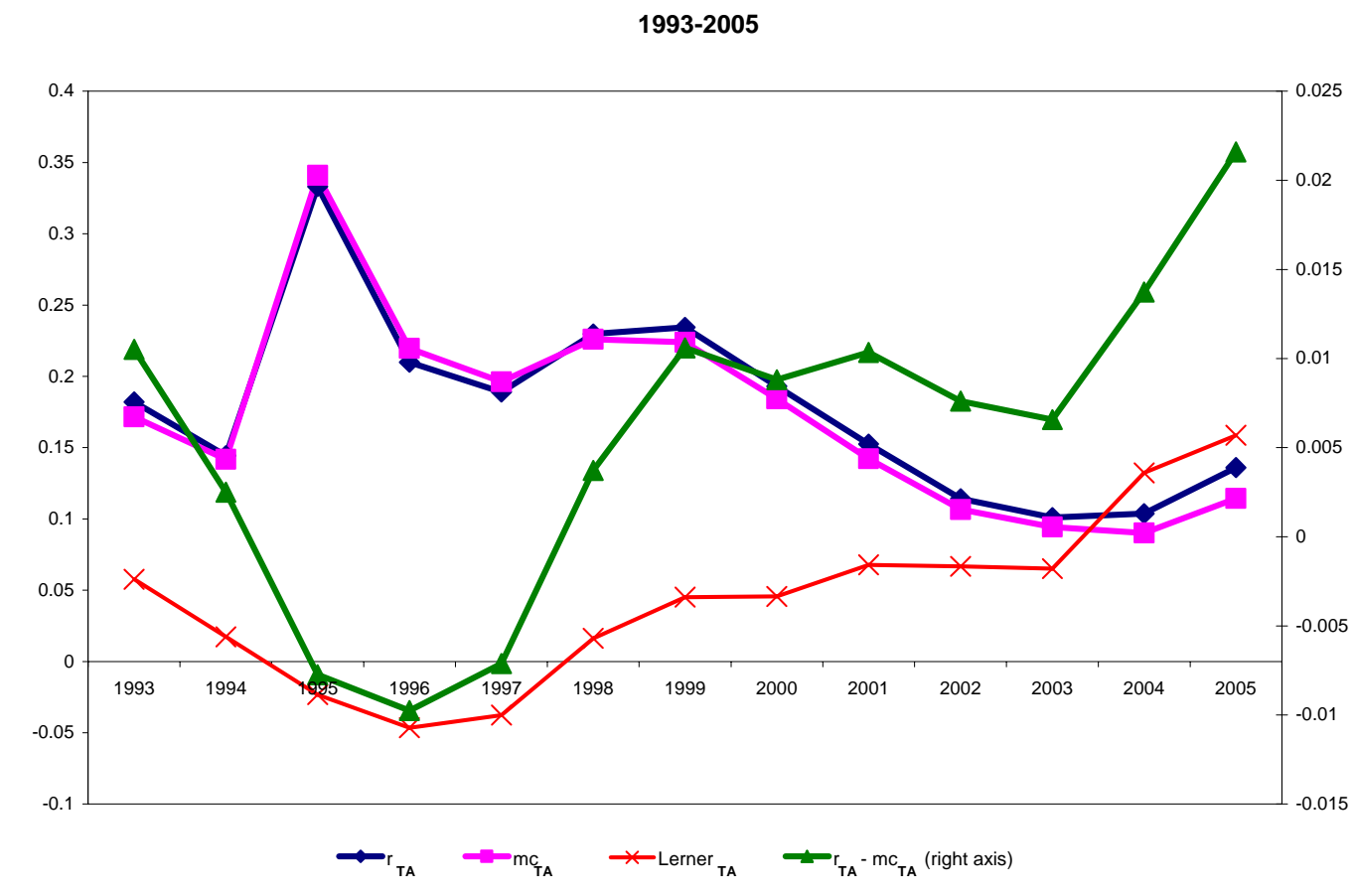

Source: Own elaboration based on data from Comisión Nacional Bancaria y de Valores and Banco de México.

private sector had been completed, an increase in competition took place ${ }^{20}$. During the exchange rate crisis and the period of recuperation, the level of competition presents certain stability. Finally, once the restrictions on the entry of foreign capital were completely lifted and the main banking institutions were acquired by foreign groups, competitive rivalry decreased though with differential behavior in the markets for loans (where it decreased) and deposits (where it increased), perhaps as a consequence of the mergers of the principal banks. This result is consistent with the evidence presented by Dueñas (2003) who finds deterioration in competition and an increase in the profitability of Mexican financial institutions as a consequence of the opening-up of the banking sector to foreign banks.

\subsubsection{Robustness test}

With the aim of testing the sensitivity of the results obtained, in this section we carry out two robustness tests. The first analyses the sensitivity of results to changes in the period of time analyzed. In the second case, we analyze whether the inclusion of

20 The fall in the Lerner index in the period following privatisation is consistent with the supercompetition found by Gruben and McComb (2003) for the same period. 
non-financial revenues (using therefore total revenues) affects the robustness of the results obtained so far in terms of financial revenues.

In the first case, we divide the sample into two sub-periods: from 1993 to 1996 and from 1997 to 2005. There are two reasons for choosing these two sub-samples. Firstly, as commented earlier, from 1997 to 2005 there was a process of consolidation of the Mexican banking system in which foreign investment was allowed entry through mergers and acquisitions. And secondly, and closely related to the previous point, from 1997 onwards there was an increase in the degree of concentration of the market, which could affect the intensity of competition.

As shown in Table 2, in both sub-samples, the Panzar and Rosse $H$-statistic is statistically greater than zero and less than one at $1 \%$ of significance, so in both cases the results are compatible with the existence of monopolistic competition. In the subperiod 1997-05 it is not possible to reject the hypothesis that the sum of the elasticities of ROA to input prices is equal to zero, thus guaranteeing long term equilibrium. However, for the sub-period 1993-96 this hypothesis is rejected, so long term equilibrium is not guaranteed, i.e. the input prices are correlated with industry returns. According to Shaffer (2004), the implication of this result is that the rejection of $H=1$ might be spurious and the rejection of $H<0$ in the revenue equation remains valid even if the sample is not in long-run equilibrium. As there is not a long term equilibrium for the sub-period 1993-96, the $H$-statistic can not be meaningfully interpreted, so no comparison can be made between the $H$-statistics for the two sub-periods.

In terms of the evolution of the Lerner index (Figure 6), the results for both subperiods are consistent with those obtained for the complete period 1993-05, though with differences of level. Thus, the separate estimation for the first sub-period shows a negative value of the Lerner index for loans only in 1993. On the other hand, the Lerner index for deposits is always positive. In the second sub-period, we observe that the upward (downward) evolution of the Lerner index for deposits (loans) is maintained, the most stable being the Lerner index for deposits for 1999-03.

The second test of robustness uses total revenue as the dependent variable in equation (3) instead of financial revenues (Table 3). Both in the complete period 199305 and in the sub-periods 1993-96 and 1997-05 the $H$-statistic is statistically greater than zero and less than one, results compatible with the existence of monopolistic competition. It is not possible to reject the hypothesis that the sum of the ROA elasticities to the price of inputs is equal to zero, guaranteeing long term equilibriums for the periods 1993-05 and 1997-05. However, once again the existence of long term equilibrium for the sub-period 1993-96 is rejected, so the $H$ - statistic cannot be 
meaningfully interpreted. Consequently, no comparison can be made between the $H$ statistics for the two sub-periods.

TABLE 2: $\boldsymbol{H}$-statistic by sub-periods

\begin{tabular}{|c|c|c|}
\hline Variable & $93-96$ & $97-05$ \\
\hline \multirow[t]{2}{*}{$\ln \left(w_{1}\right)$} & -0.051 & 0.068 \\
\hline & $(-0.47)$ & $(1.57)$ \\
\hline \multirow{2}{*}{$\ln \left(w_{2}\right)$} & 0.481 * & 0.554 * \\
\hline & $(6.41)$ & $(8.31)$ \\
\hline \multirow[t]{2}{*}{$\ln \left(w_{3}\right)$} & -0.052 & -0.083 \\
\hline & $(-1.23)$ & $(-1.60)$ \\
\hline \multirow[t]{2}{*}{$\ln \left(E_{1}\right)$} & 0.055 & 0.050 \\
\hline & $(0.37)$ & $(0.79)$ \\
\hline \multirow[t]{2}{*}{$\ln \left(E_{2}\right)$} & 0.541 * & 0.397 * \\
\hline & $(3.01)$ & $(5.03)$ \\
\hline \multirow[t]{2}{*}{$\ln \left(E_{3}\right)$} & -0.148 & 0.226 * \\
\hline & $(-1.64)$ & $(3.57)$ \\
\hline \multirow{4}{*}{$\begin{array}{l}\text { Hausman Test } \\
\text { p-value } \\
\text { Observations } \\
\mathrm{R}^{2}\end{array}$} & 45.92 & 130.15 \\
\hline & $(0.000)$ & $(0.000)$ \\
\hline & 85 & 218 \\
\hline & 0.9523 & 0.890 \\
\hline H-statistic & $0.377^{\mathrm{MC}}$ & $0.539 \mathrm{MC}$ \\
\hline \multirow{2}{*}{$\begin{array}{l}\mathrm{H}=0 \text { (p-value) } \\
\mathrm{H}=1 \text { (p-value })\end{array}$} & {$[0.026]$} & {$[0.000]$} \\
\hline & $(0.000)$ & $(0.000)$ \\
\hline \multirow{2}{*}{$\begin{array}{c}\mathbf{E} \\
p \text {-value } E=0\end{array}$} & 2.355 & $0.409^{\text {LR }}$ \\
\hline & $(0.092)$ & $(0.444)$ \\
\hline \multicolumn{3}{|c|}{ Dependent variable: In(Financial income/Total assets) } \\
\hline \multicolumn{3}{|c|}{ Estimations with fixed effects and time effects } \\
\hline \multicolumn{3}{|c|}{ The reported t-statistics are based on robust standard errors } \\
\hline \multicolumn{3}{|c|}{ t-statistics are in parentheses } \\
\hline \multicolumn{3}{|c|}{ * Significant at $1 \%,{ }^{* *}$ significant at $5 \%$, and ${ }^{* \star}$ significant at $10 \%$. } \\
\hline \multicolumn{3}{|c|}{ E: Sum of the elasticities of ROA to the prices of inputs } \\
\hline \multicolumn{3}{|c|}{ MC: Monopolistic Competition } \\
\hline \multicolumn{3}{|c|}{ LR: Long Run Equilibrium } \\
\hline
\end{tabular}

It is also of interest to analyze the robustness of the Lerner index estimated for banking activity as a whole to variations in the period of time (Figure 7) and to the inclusion of non financial revenue (Figure 8). In the first case, the results show that the upward evolution is maintained even though there is a difference in levels. In the second case, the temporal evolution is similar although, logically, the value of the Lerner index increases when non-financial revenue is incorporated into the calculation of the average price of loans. 
FIGURE 6. Lerner index: estimation by sub-periods

1993-1996

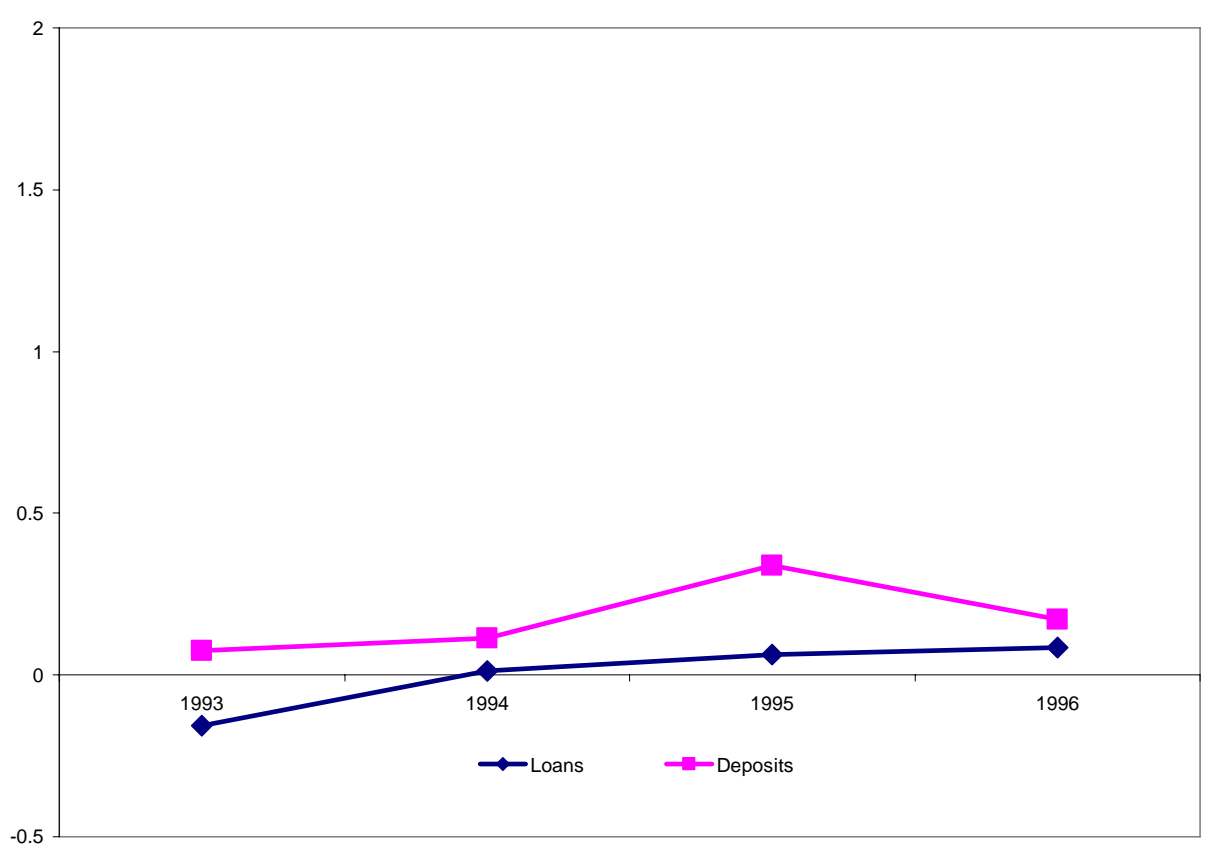

Source: Own elaboration based on data from Comisión Nacional Bancaria y de Valores and Banco de México.

1997-2005

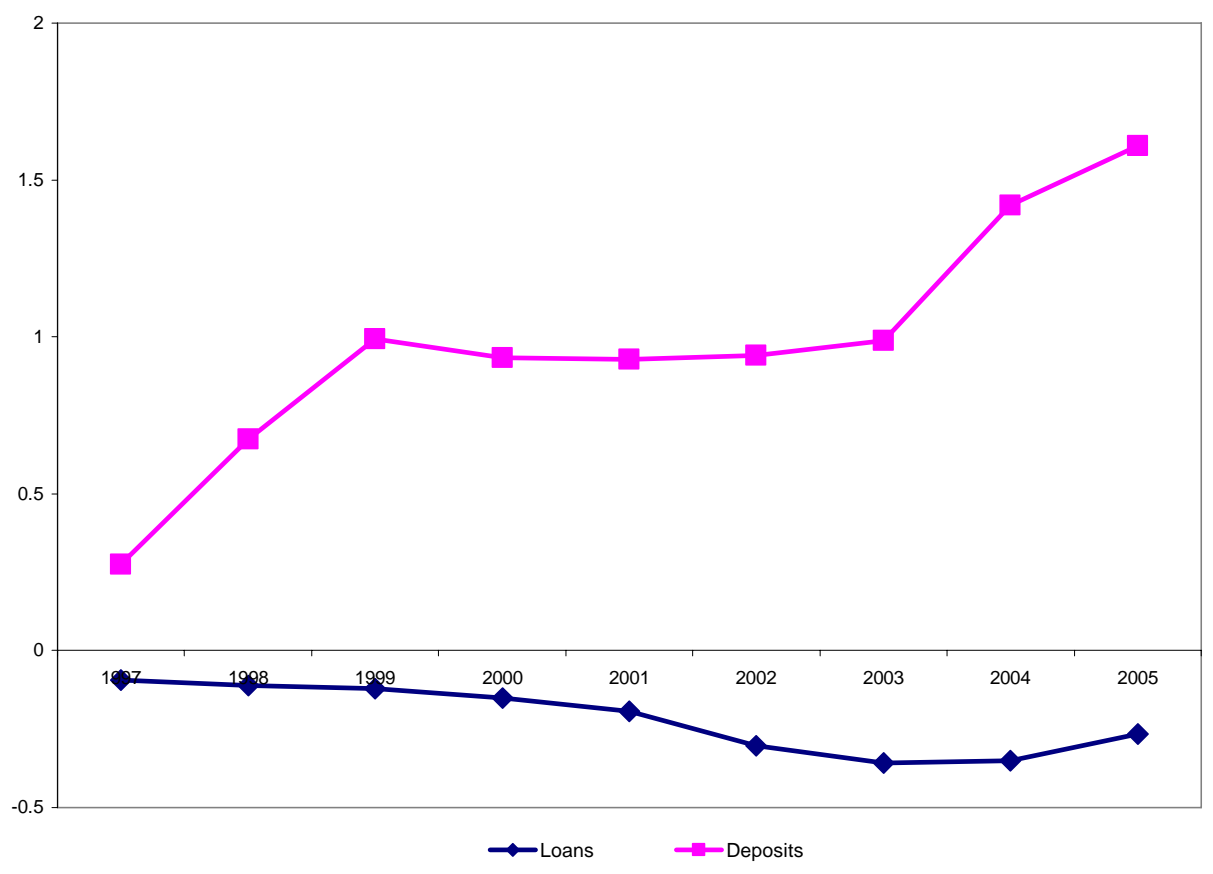

Source: Own elaboration based on data from Comisión Nacional Bancaria y de Valores and Banco de México. 
TABLE 3. $H$-statistic: total income

\begin{tabular}{|c|c|c|c|}
\hline Variable & $93-05$ & $93-96$ & $97-05$ \\
\hline \multirow[t]{2}{*}{$\ln \left(w_{1}\right)$} & 0.097 ** & -0.059 & 0.094 ** \\
\hline & (2.49) & $(-0.52)$ & 2.35 \\
\hline \multirow[t]{2}{*}{$\ln \left(w_{2}\right)$} & 0.467 * & 0.534 * & 0.480 * \\
\hline & $(8.44)$ & $(6.67)$ & 8.01 \\
\hline \multirow[t]{2}{*}{$\ln \left(w_{3}\right)$} & $-0.061 * \star \star *$ & -0.039 & -0.047 \\
\hline & $(-1.96)$ & $(-0.92)$ & -1.01 \\
\hline \multirow[t]{2}{*}{$\ln \left(E_{1}\right)$} & 0.061 & 0.033 & 0.036 \\
\hline & (1.08) & $(0.23)$ & 0.64 \\
\hline \multirow[t]{2}{*}{$\ln \left(E_{2}\right)$} & 0.333 * & 0.624 * & 0.396 * \\
\hline & $(4.25)$ & $(3.42)$ & 5.45 \\
\hline \multirow[t]{2}{*}{$\ln \left(E_{3}\right)$} & 0.197 * & -0.080 & 0.249 * \\
\hline & (3.67) & $(-0.90)$ & 4.04 \\
\hline Hausman Test & 115.34 & 45.35 & 117.18 \\
\hline $\mathrm{p}$-value & $(0.000)$ & $(0.000)$ & $(0.000)$ \\
\hline Observations & 303 & 85 & 218 \\
\hline $\mathrm{R}^{2}$ & 0.864 & 0.947 & 0.887 \\
\hline H-statistic & $0.502^{M C}$ & $0.436^{\mathrm{MC}}$ & $0.527^{M C}$ \\
\hline $\mathrm{H}=0$ (p-value $)$ & {$[0.000]$} & [0.019] & [0.000] \\
\hline $\mathrm{H}=1$ ( $p$-value $)$ & $(0.000)$ & $(0.003)$ & $(0.000)$ \\
\hline$E$ & $0.339^{\mathrm{LR}}$ & 2.355 & $0.409^{\text {LR }}$ \\
\hline$p$-value $E=0$ & $(0.402)$ & $(0.092)$ & $(0.444)$ \\
\hline \multicolumn{4}{|c|}{ Dependent variable: $\ln ($ Total income/Total assets) } \\
\hline \multicolumn{4}{|c|}{ Estimations with fixed effects and time effects } \\
\hline \multicolumn{4}{|c|}{ The reported t-statistics are based on robust standard errors } \\
\hline \multicolumn{4}{|c|}{ t-statistics are in parentheses } \\
\hline \multicolumn{4}{|c|}{ * Significant at $1 \%$, ** significant at $5 \%$, and ${ }^{\star * \star}$ significant at $10 \%$. } \\
\hline \multicolumn{4}{|c|}{$E$ : Sum of the elasticities of ROA to the prices of inputs } \\
\hline \multicolumn{4}{|c|}{ MC: Monopolistic Competition } \\
\hline LR: Long Run Equilibrium & & & \\
\hline
\end{tabular}


FIGURE 7. Lerner index in total banking activity: estimation by sub-periods

1993-1996

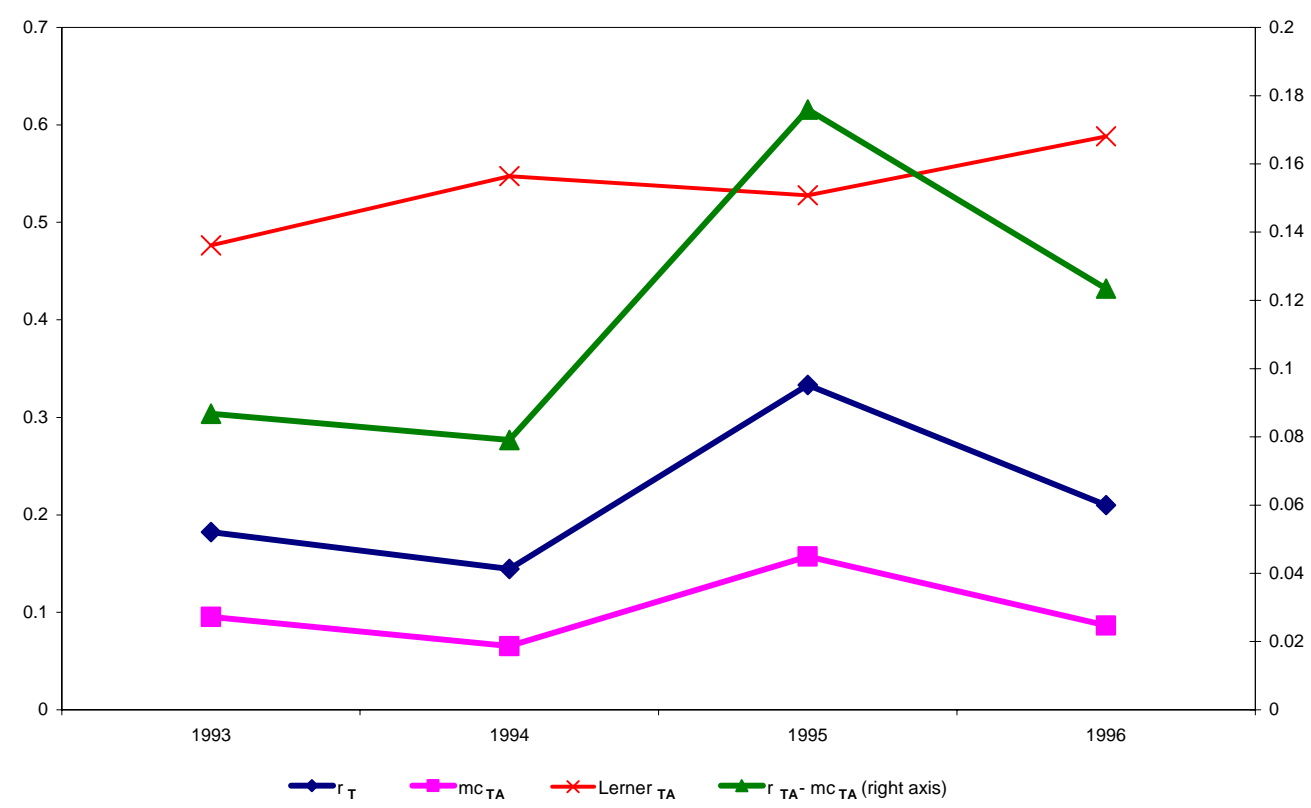

Source: Own elaboration based on data from Comisión Nacional Bancaria y de Valores and Banco de México.

1997-2005

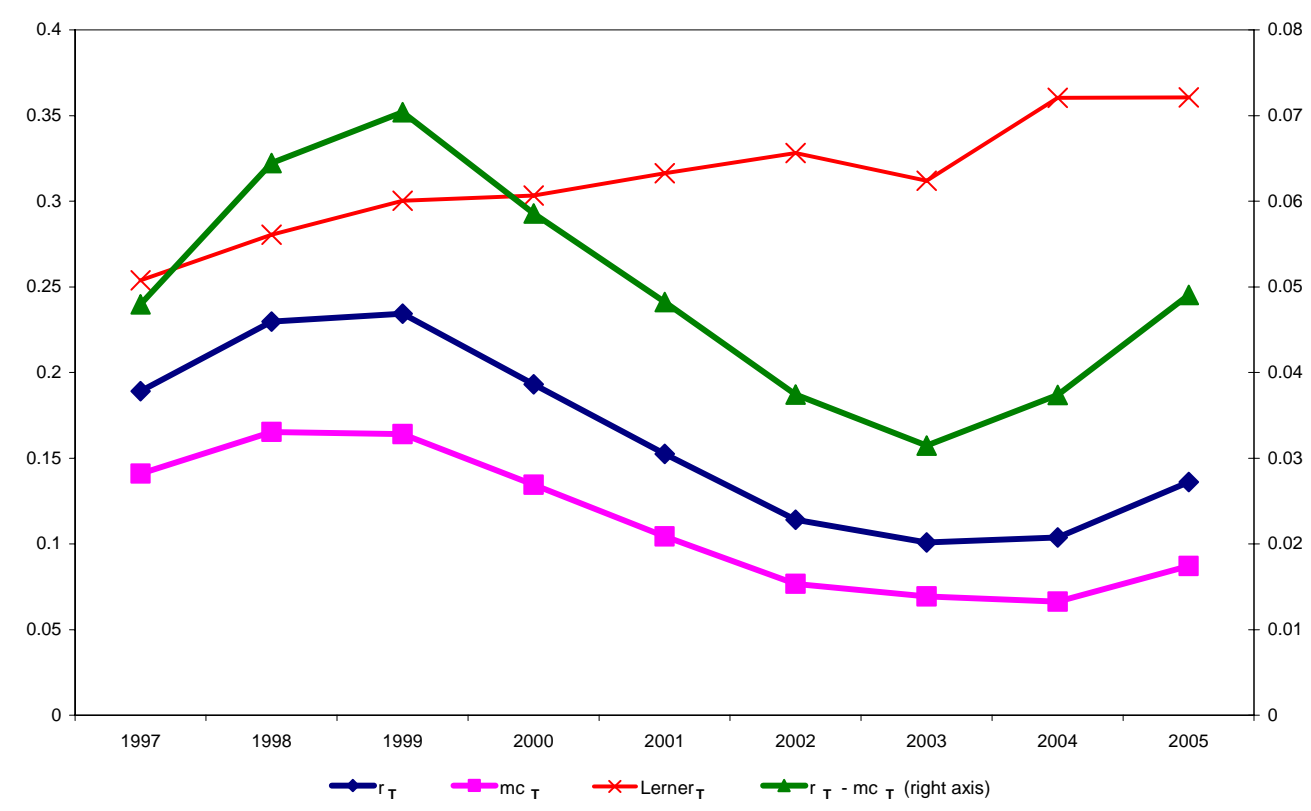

Source: Own elaboration based on data from Comisión Nacional Bancaria y de Valores and Banco de México. 


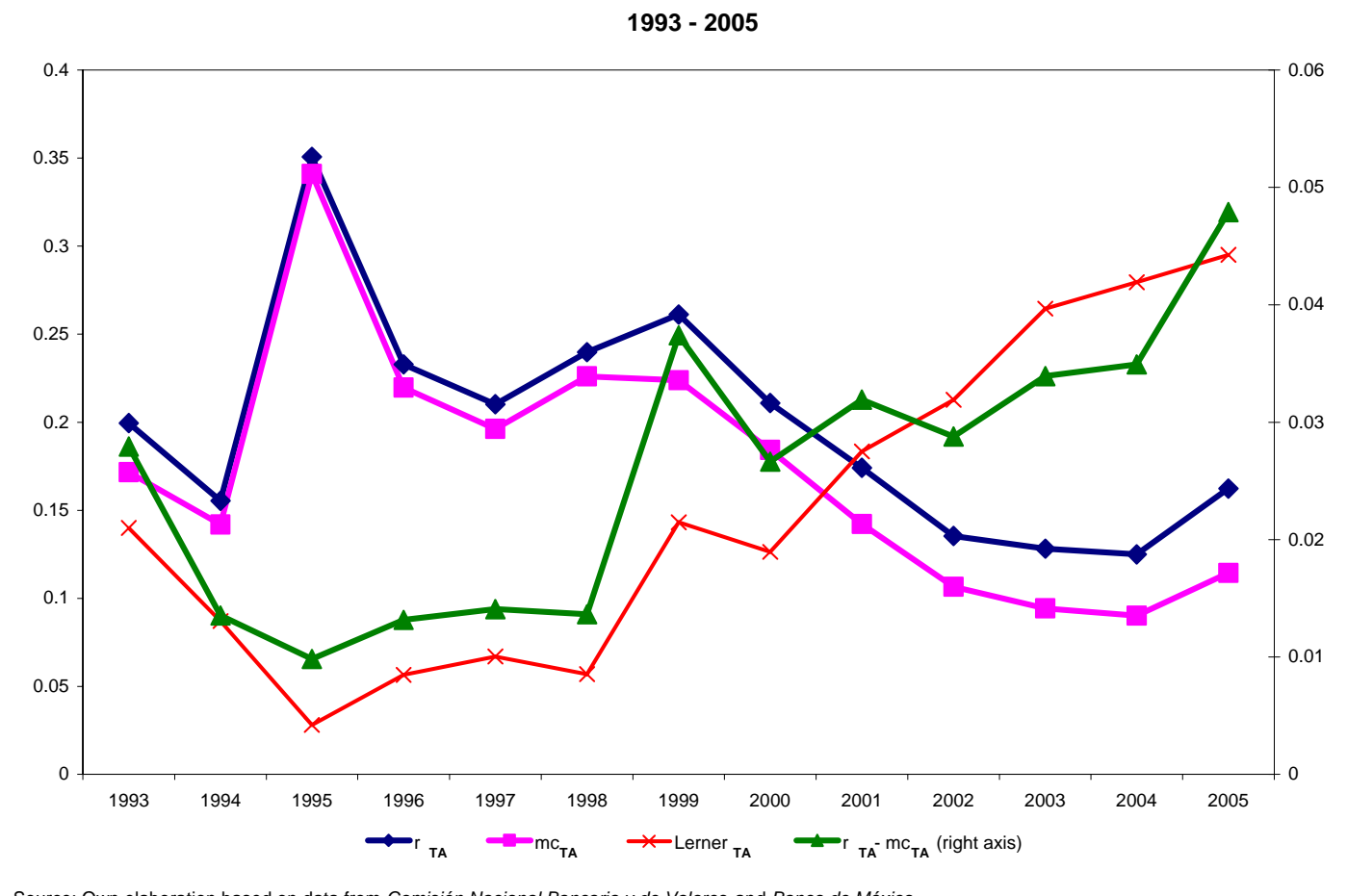

\section{Conclusions}

The Mexican banking system has been subjected to major transformations as a consequence of the processes of nationalization (1982), privatization (1991), exchange rate crisis (December 1994), gradual opening-up to foreign investment (starting in 1994), and its consolidation from 2000 onwards with mergers among the principal banks.

In this context of structural change, this paper analyses the evolution of the degree of competition in the Mexican banking system from 1993 to 2005 using two instruments from the theory of industrial organization: the Panzar and Rosse $H$-statistic and the Lerner index of market power. Compared to other studies of the Mexican banking system, this one presents various novelties. Firstly, and for the first time in the Mexican banking system, it uses the Lerner index to measure the evolution of market power. The advantage of using it is that it permits the evolution of competition to be analyzed with greater precision, and market power to be measured separately for the loans and deposits markets. Second, the analysis covers a long period, over which it can 
be observed whether the measures adopted (both privatization and the opening-up to foreign investment) have increased competition in the Mexican banking system. Previous studies have analyzed the consequences only of privatization (Gruben and McComb, 2003) or of the opening-up to foreign investment (Dueñas, 2003). And thirdly, banking competition is analyzed using two indicators (the $H$-statistic of Panzar and Rosse, and the Lerner index).

The empirical evidence offered by the $H$-statistic does not permit us to reject the existence of monopolistic competition, a result that is consistent with those of Dueñas (2003) for the period from January 1997 to September 2002, Claessens and Laeven (2004) for the period 1994 to 2001 and Gelos and Roldós (2004) from 1994 to 1999. The estimation of the $H$-statistic separately for the sub-periods 1993-96 and 1997-05 does not permit rejection in either case of the existence of a situation of monopolistic competition, though long term equilibrium for the sub-period 1993-96 is rejected.

The separate evolution of the Lerner index for each of the two banking markets analyzed shows that, from 1993 to 2005, market power decreased in the loans market while it increased in the deposits market. By sub-periods, with the crisis there occurred an increase in inflation and in interest rates, leading to greater market power both in loans and in deposits.

Following the crisis, there was a decrease in credit activity, asset margins being practically nil. On the other hand, in this period the banks worked with very high liability margins. From 1997 to 2005, there was cross-subsidization in the services offered by the Mexican banking system, granting loans with very small and even negative margins (with the aim of attracting or keeping clients), recuperating this loss by setting higher margins on deposits. Results show that the net effect of this cross subsidization strategy, together with the increase in activity with repos, was highly profitable for the banks, as shown by the fact that the levels of profitability (ROA) have increased substantially since 1998. In fact, the Lerner index in the total banking activity presents a clearly increasing evolution from 1997 onwards, so that the value of the index more than triples until it reaches its highest value in 2005, reflecting a deterioration in competition.

The robustness tests carried out show that the results are sustained in all cases. Thus, the evolution of the Lerner index is very similar when replicated separately for the sub-periods 1993-96 and 1997-05 (before and after the entry of foreign capital into the Mexican banking system) or when the total revenue is considered (including therefore financial and non-financial revenue). 
The results obtained permit us to conclude that the measures adopted and the transformations experienced by the Mexican banking system during recent years have not in general translated into greater competitive rivalry. Specifically, the results indicate that once the sale of the commercial banks to the private sector had been completed, the intensity of competition increased.

Subsequently, the exchange rate crisis had an adverse effect on inflation and on interest rates, inducing an increase in market power in loans and deposits. Finally, once the restrictions on the entry of foreign capital had been completely eliminated in 1998, market power increased in deposits, while it decreased in the loans market, consolidating the following of a cross subsidization strategy. Consequently, it is possible that part of the recent growth of the profitability levels of the Mexican banking system is due to a decrease in competitive rivalry in the banking markets, which would permit us to call into question the efficacy of the measures so far implemented. 


\section{References}

Angelini, P., Cetorelli, N., 2003. "The effects of regulatory reform on competition in the banking industry". Journal of Money, Credit and Banking 35, 663-684.

Asociación Mexicana de Banqueros. La Banca en México, Historia 1982-1996 (http://www.abm.org.mx/banca_mexico/historia.htm).

Bikker, J.A., Haaf, K., 2002. "Competition, concentration and their relationship: an empirical analysis of the banking industry". Journal of Banking and Finance 26, 2191-2214.

Carbó, S., Fernández de Guevara, J., Humphrey, D., Maudos, J., 2005. "Estimating the intensity of price and non-price in banking: an application to the Spanish case". DT 05-02, Fundación BBVA.

Carbó, S., Rodriguez, F., 2003a. "Medición de la competencia en los mercados bancarios de las regiones españolas". Revista de Economía Aplicada 3 (9), 5-33.

Carbó, S., Humphrey D., Rodriguez, F., 2003b. "Bank deregulation is better than mergers". Journal of International Financial Markets, Institutions and Money Vol. XIII, n ${ }^{\circ}$ 5, 429449 .

Carbó, S., Humphrey D., Rodriguez, F., 2003c. "Deregulation, Bank Competition and Regional Growth”. Regional Studies 37(3), 227-237.

Claessens, S., Laeven, L., 2004. "What Drives Bank Competition? Some International Evidence". Journal of Money, Credit, and Banking Vol. 36, No. 3, 563-583.

Claessens, S. Demirgüç-Kunt, A., Huizinga, H., 2000. "How does foreign entry affect domestic banking markets?". Journal of Banking and Finance 25(5), 891-911.

Comisión Nacional Bancaria y de Valores, several years. "Boletín Estadístico de Banca Múltiple". México.

De Bandt, O., Davis, E. P., 2000. "Competition, contestability and market structure in European banking sectors on the eve of EMU". Journal of Banking \& Finance 24, 1045-1066.

Demirgüç-Kunt, A. Levine, R., Min, H.-G., 1998. "Opening to Foreign Banks: Issues of Stability, Efficiency and Growth" in The Implications of Globalization of World Financial Markets, The Bank of Korea.

Drakos, K., Konstantinou, P., 2005. "Competition and contestability in transition banking: An empirical analysis”. South-Eastern Europe Journal of Economics 2, 183-209.

Dueñas, R., 2003. "Metodología de Panzar y Rosse para la medición de competencia en la banca mexicana a partir de la entrada de capital extranjero (1997-2002)". Gaceta de Economía Año 9, Núm. 17, 141-170.

Fernández de Guevara, J., Maudos, J. Pérez, F., 2007. "Integration and competition in European banks". Journal of International Money and Finance 26, 26-45. 
Fernández de Guevara, J., Maudos, J., Pérez, F., 2005. "Market Power in European Banking Sectors". Journal of Financial Services Research Vol. 27 (2), 109-138.

Freixas, X., Rochet, J.C., 1997. Microeconomics of Banking, Massachussetss Institute of Technology, MIT Press.

Gelos, R.G., Roldós, J., 2004. "Consolidation and market structure in emerging market banking system". Emerging Markets Review 5, 39-59.

Gruben, W., McComb, R., 2003. "Privatization, competition and supercompetition in the Mexican commercial banking system". Journal of Banking \& Finance 27, 229-249.

Gruben, W., McComb, R., 1997. "Liberalization, privatization, and crash: Mexico's banking system in the 1990". Federal Reserve Bank of Dallas Economic Review First Quarter, 21-30.

Haber, S., 2005. "Mexico's experiments with bank privatization and liberalization, 1991-2003". Journal of Banking \&d Finance 29, 2325-2353.

Ho, T., Saunders, A., 1981. "The determinants of banks interest margins: theory and empirical evidence". Journal of Financial and Quantitative Analysis XVI, No. 4, 581-600

Kaminsky, G., Reinhart, C., 1999. "The Twin Crises: The Causes of Banking and Balance of Payments Problems". American Economic Review 89 (3), 473-500.

Levine, R., 1996. "Foreign Bank, Financial Development, and Economic Growth". International Financial Markets: Harmonization versus Competition, Edited by C.E. Barfield. Washington, D.C. The American Enterprise Institute Press 224-254.

López de Silanes, F., Zamarripa, G., 1995. "Deregulation and Privatization of Commercial Banking”. Revista de Analisis Económico 10 (November): 113-164.

Maudos, J., Fernández de Guevara, J., 2007. "The cost of market power in the European banking sectors: social welfare loss vs. inefficiency cost", Journal of Banking \& Finance 37 (7), 2103-2125.

Maudos, J., Fernández de Guevara, J., 2004. "Factors explaining the interest margin of the banking sectors of the European Union". Journal of Banking \& Finance 28(9), 22592281.

Maudos, J., Pérez, F., 2003. "Competencia versus poder de mercado en la banca española". Moneda y Crédito 217, 139-166.

Molyneux, P., Lloyd-Williams. W., Thornton, J., 1994. "Competitive Conditions in European Banking”. Journal of Banking \& Finance 18, 445-459.

Murillo, J., 2002. "La banca en México: privatización, crisis y reordenamiento". Working Paper, Banco de Mexico.

Nathan, A., Neave, E., 1989. "Competition and contestability in Canada's financial system: empirical result". Canadian Journal of Economics XXII, No. 3, 576-594. 
Panzar J., Rosse, J., 1987. "Testing for Monopoly' Equilibrium”. Journal of Industrial Economics 35, 443-456

Shaffer, S., 2004. "Patterns of competition in banking". Journal of Economics and Business 56, 287-313.

Shaffer, S., 2002. "Conduct in a banking monopoly". Review of Industrial Organization 20, 221-238

Unal H., Navarro M., 1999. "The Technical Proces of Bank Privatization in Mexico". Journal of Financial Services Research 16 (1), 61-83. 